\title{
Hydrochloric acid inhalation: who needs admission?
}

\author{
Stephen H Boyce, Kenneth A Simpson
}

\begin{abstract}
Nine pharmaceutical workers were exposed to hydrochloric acid (HCl) fumes. Four were discharged with no symptoms after a $4 \mathrm{~h}$ observation period in the accident and emergency (A\&E) department. The remaining five were admitted to the medical unit because of severe symptoms, reduced peak expiratory flow rate (PEFR), or hypoxaemia. Treatment was symptomatic and discharge followed $24 \mathrm{~h}$ later. Only one patient, discharged from the medical unit, developed long term airway hyper-reactivity, superimposed on a background of chronic obstructive airways disease. Thus patients who are minimally symptomatic with normal PEFR and oxygen saturation values can be safely discharged from the A\&E department after a short observation period of $4 \mathrm{~h}$ with advice to return if dyspnoea occurs. Caution should be employed in severely symptomatic patients, those with pre-existing lung pathology or reduced PEFR, and hypoxaemic patients, where observation for at least $24 \mathrm{~h}$ is recommended. $(F$ Accid Emerg Med 1996;13:422-424)
\end{abstract}

Key terms: hydrochloric acid fumes; admission; management

Hydrochloric acid $(\mathrm{HCl})$ can produce adverse effects after inhalation, ingestion, and skin or ocular contamination. We report the signs, symptoms, investigations and management of nine pharmaceutical workers who were exposed to $\mathrm{HCl}$ fumes.

The incident occurred during the open air unloading of industrial strength $\mathrm{HCl}$ from a transport container. A small quantity of acid escaped, releasing fumes which enveloped the workers for approximately 15 seconds, before dispersing into the atmosphere.

No therapeutic measures were carried out by the firm's attending first aid and nursing team. Arrangements were made for immediate transfer to the accident and emergency (A\&E) department.

Mr Kenneth Simpson, 24 Strawberry Bank, Dundee DD2 $1 \mathrm{BH}$.

Accepted for publication 15 July 1996
Case reports

The history, physical findings and investigations for each patient are presented in the table.
Patients 1-4 were observed in the $A \& E$ department until four hours after the incident, when they were discharged home as symptoms had resolved and repeat observations were within normal limits.

Patients 5-9 were admitted to the medical unit for observation. The criteria for admission were symptom severity, pre-existing lung pathology, abnormal peak expiratory flow rate (PEFR), or reduced oxygen saturation. Patients 5,6 , and 8 received only high flow oxygen at 15 litres/min through a tight fitting face mask and reservoir bag. Patients 7 and 9 were treated with $5 \mathrm{mg}$ of nebulised salbutamol driven with oxygen. Patient 7 alone received oral steroids (prednisolone $60 \mathrm{mg}$ for $24 \mathrm{~h}$ ). The indications for this were unclear and not recorded. Chest $x$ rays were performed on all the patients admitted and were reported as normal. These patients were all discharged after $24 \mathrm{~h}$, and follow up was arranged only for patient 9 , who was reviewed four weeks later. $\mathrm{He}$ complained of a morning cough and wheeze. Pulmonary function tests were performed and a partially reversible airway obstruction was diagnosed secondary to preexisting chronic obstructive airways disease (COAD). He was started on $\beta_{2}$ agonist and steroid inhalers.

During the next five weeks three patients re-attended the A\&E department. Patient 3 returned two days later complaining of chest tightness and an irritant cough. PEFR and oxygen saturation values were normal. He was treated with $5 \mathrm{mg}$ of nebulised salbutamol and discharged after symptomatic improvement. Patient 6 returned one week later complaining of dyspnoea. Examination revealed no abnormality; however, PEFR was reduced at 310 litres/min. He was treated with $5 \mathrm{mg}$ of nebulised salbutamol and discharged after satisfactory improvement. No follow up was planned in either of these cases. Patient 4 returned five weeks later with left pleuritic pain and mildly febrile at $37.7^{\circ} \mathrm{C}$. Chest $x$ ray showed patchy opacification at the left base consistent with a pneumonic process. $\mathrm{He}$ was admitted to the medical ward, treated with antibiotics, and discharged the next day with a diagnosis of basal pneumonia. This episode was felt to be unrelated to the original exposure and no follow up planned. 
History, physical findings, and investigations

\begin{tabular}{|c|c|c|c|c|c|c|c|c|c|c|c|}
\hline $\begin{array}{l}\text { Patient } \\
\text { No }\end{array}$ & $\begin{array}{l}\text { Age } \\
\text { (years) }\end{array}$ & Smoker & $\begin{array}{l}\text { Respiratory } \\
\text { disease }\end{array}$ & Symptoms at presentation & $\begin{array}{l}\text { Pulse } \\
\text { beats/min }\end{array}$ & $\mathrm{BP} \mathrm{mm} \mathrm{Hg}$ & $\begin{array}{l}\text { Resp rate } \\
\text { per min }\end{array}$ & $\begin{array}{l}\text { PEFR } \\
\text { litres/min }\end{array}$ & $\mathrm{SaO}_{2}$ air & $\begin{array}{l}\mathrm{SaO}_{2} 15 \\
\text { litres/min } \mathrm{O}_{2}\end{array}$ & $\begin{array}{l}\text { Chest } \\
\text { examination }\end{array}$ \\
\hline 1 & 25 & Yes & No & None & 89 & $145 / 65$ & - & 550 & 97 & - & Normal \\
\hline 2 & 33 & Yes & No & Headache & 80 & $140 / 75$ & - & 650 & 98 & - & Normal \\
\hline 4 & 29 & Yes & No & Chest tightness & 100 & - & - & 650 & 97 & - & Normal \\
\hline 5 & 25 & No & No & Chest tightness, heavy eyes & 82 & $130 / 70$ & 20 & 560 & 98 & - & Normal \\
\hline 6 & 50 & Yes & No & $\begin{array}{l}\text { Mild headache, painful eyes, } \\
\text { burning throat, retrosternal } \\
\text { burning, chest tightness }\end{array}$ & 52 & $160 / 60$ & 14 & 450 & 97 & - & Normal \\
\hline 7 & 25 & Ex & No & $\begin{array}{l}\text { Light-headedness, nausea, mild } \\
\text { dyspnoea, burning throat }\end{array}$ & 88 & $150 / 60$ & 14 & 350 & 93 & 97 & Normal \\
\hline 8 & 34 & No & Asthma & $\begin{array}{l}\text { Chest tightness, burning throat } \\
\text { and eyes, dyspnoea }\end{array}$ & 96 & $140 / 90$ & 22 & 650 & 92 & 99 & Normal \\
\hline 9 & 51 & Yes & COAD & $\begin{array}{l}\text { Headache, dyspnoea, chest } \\
\text { tightness, non-productive cough }\end{array}$ & 91 & $140 / 70$ & - & 200 & 98 & - & Normal \\
\hline
\end{tabular}

COAD, chronic obstructive airways disease; BP, blood pressure; PEFR, peak expiratory flow rate

\section{Discussion}

Hydrochloric acid inhalation in humans has been shown to cause damage to the upper and lower respiratory tracts, resulting in mucous membrane irritation, ${ }^{1}$ prolonged hypoxaemia, ${ }^{23}$ increased airway irritability, ${ }^{4}$ bronchoconstriction, ${ }^{35}$ laryngeal and alveolar oedema, ${ }^{3}$ and asthma. ${ }^{6}$ Symptoms on presentation ${ }^{7}$ include ocular irritation, headache, cough, pharyngeal and retrosternal discomfort, wheeze, dyspnoea, and stridor. Pulmonary oedema may be delayed in onset ${ }^{78}$ for $2-24$ hours.

Emergency treatment ${ }^{79}$ consists of removal from exposure and administration of high flow oxygen. Nebulised $\beta_{2}$ agonists are indicated for bronchospasm. Diuretics are of no value in pulmonary oedema, but high dose corticosteroids (prednisolone $60-80 \mathrm{mg}$ daily) are indicated. Their use, however, is controversial, some authorities feeling that little benefit is gained. $^{7}$ Advanced airway techniques may be required for laryngeal oedema.

In the last 20 years, few studies relevant to acute $\mathrm{HCl}$ inhalation in humans have been published. Most laboratory studies have been performed on animal models and are therefore of questionable relevance in human exposure. ${ }^{10-12}$

One study ${ }^{3}$ used laboratory tests to monitor lung function in 11 patients who accidentally inhaled a mixture of noxious fumes including $\mathrm{HCl}$. The lung function abnormalities recorded resolved within a short time. Another paper also showed no long term adverse health effects of $\mathrm{HCl}$ inhalation by young adult asthmatics. ${ }^{13}$

However, a case of asthma has been reported following inhalation of sodium hypochlorite and $\mathrm{HCl}$, which persisted for two years. ${ }^{6}$ This is supported by two other papers, ${ }^{24}$ which cite asthma as an adverse effect of exposure to $\mathrm{HCl}$.

On the basis of these studies no generalisations can be drawn regarding long term sequelae of $\mathrm{HCl}$ inhalation in either normal subjects or those with pre-existing asthma.

\section{CONCLUSION}

None of the nine patients described in this report required respiratory support other than oxygen by mask. The exposure to $\mathrm{HCl}$ appears to have been mild in all cases. One case resulted in long term morbidity occurring on a background of COAD. Pulmonary oedema did not occur. The important decision to be made in the $A \& E$ department is which patients are safe to send home. Some authorities recommend observation for 24 hours in hospital where other than minimal exposure to respiratory irritants has occurred. ${ }^{89}$ In the case of mild exposure, the observation period has not been specified. On the basis of our findings, an observation period of four hours postexposure appears sufficient to detect any serious consequence where a minimally symptomatic patient has a normal PEFR and oxygen saturation on presentation. Caution should be employed in severely symptomatic patients, those with pre-existing lung pathology or reduced PEFR, and hypoxaemic patients (confirmed by arterial blood gas analysis), where we recommend observation for at least 24 hours. Because of the delayed onset of pulmonary oedema, a chest $x$ ray is not a useful initial screening test for admission and should only be employed in patients with pre-existing lung disease or in those who deteriorate clinically. These recommendations could also apply to inhalation of other chemical irritants such as ammonia, chlorine, nitrogen dioxide, sulphur dioxide, and hydrogen fluoride. ${ }^{9}$

We would like to thank the company involved in this incident for their help, Mr James Stevenson, consultant in accident and emergency, for his guidance, and Michelle Loughlin for word processing.

1 Speizer FE. Environmental lung diseases. In: Wilson JD et al, eds. Harrison's Principles of internal medicine, 12 th ed, vol II. New York: McGraw-Hill, 1991:1056-63.

2 Finnegan MJ, Hodson ME. Prolonged hypoxaemia following inhalation of hydrogen chloride vapour. Thorax 1989;44:238-9.

3 Rosenthal T, Baum GL, Frand U, Molho M. Poisoning caused by inhalation of hydrogen chloride, phosphorus oxychloride, phosphorus pentachloride, oxalyl chloride, and oxalic acid. Chest 1978;73:623-6.

4 Boulet LP. Increases in airway responsiveness following acute exposure to respiratory irritants. Reactive airway dysfunction syndrome or occupational asthma? Chest 1988;94: 476-81.

5 Fine JM, Gordon T, Thompson JE, Sheppard D. The role of titratable acidity in acid aerosol-induced bronchoconstriction. Am Rev Respir Dis 1987;135:826-30.

6 Deschamps D, Soler P, Rosenberg N, Baud F, Gervais P. Persistent asthma after inhalation of a mixture of sodium Pypochlorite and hydrochloric acid. Chest 1994;105:18956 .

7 Toxbase, National Poisons Information Centre, Edinburgh.

8 Meyer AA, Salber PR. Burns and smoke inhalation. In: Sanders CE, Ho MT, eds. Current emergency diagnosis and treatment, 4th ed. East Norwalk: Appleton \& Lange, 1992: $697-9$.

9 Steedman DJ. Environmental medical emergencies. Oxford: Oxford University Press, 1994:126-7. 
10 Burleigh-Flayer $\mathrm{H}$, Wong $\mathrm{KL}$, Alarie $\mathrm{Y}$. Evaluation of the pulmonary effects of $\mathrm{HCl}$ using $\mathrm{CO}_{2}$ challenges in guinea pulmonary effects of $\mathrm{HCl}$ using $\mathrm{CO}_{2}$ chall
pigs. Fund Appl Toxicol 1985;5:978-85.

11 Kaplan HL, Anzueto A, Switzer WG, Hinderer RK. Effects of hydrogen chloride on respiratory response and pulmonary function of the baboon. $₹$ Toxicol Environ Health 1988; 23:473-93.
12 Stavert DM, Archuleta DC, Behr MJ, Lehnert BE. Relative acute toxicities of hydrogen fluoride, hydrogen chloride, and hydrogen bromide in nose- and pseudomouthbreathing rats. Fund Appl Toxicol 1991;16:636-55.

13 Stevens B, Koenig JQ, Rebolledo V, Hanley QS, Covert DS Respiratory effects from the inhalation of hydrogen chloride in young adult asthmatics. $\mathcal{F}$ Occup Med 1992;34:923-9.

\section{The rising prevalence of HIV-1 infection in patients attending an inner city accident and emergency department}

Mark C Poznansky, Jon Walters, Alistair Cruikshank, Robin Pollock, Peter Dendrowskyj, Kim Lewis, John V Parry, Jane Fothergill, Jonathan Weber

The recently published findings of the unlinked anonymous HIV prevalence study in England and Wales showed unchanging HIV prevalence in groups such as homo/bisexual men, and declining rates in non-injecting heterosexual men attending genitourinary medicine clinics. ${ }^{1}$ However, this multicentre study did detect a significant rise in seroprevalence rates in pregnant women in England and Wales and sentinel groups within hospitals in London, warning that changing patterns of HIV infection might account for these variable results. In 1992-1993 a seroprevalence study of adult patients attending the accident and emergency department at St. Mary's Hospital in West Central London showed a rate of HIV-1 infection of 1 in $77 . .^{2}$ We have repeated the seroprevalence study over the same calendar months in 1994-1995 to gain further information about HIV positive patients attending the department and to see whether a change in the patterns of HIV infection in the population served by $\mathrm{St}$ Mary's Hospital had occurred.

\section{Methods and results}

Anonymised blood or urine samples were obtained from 1087 consecutive new patients attending the accident and emergency (A\&E) department at St Mary's Hospital between 14 December 1994 and the 31 January 1995. No repeat samples were obtained from reattendees. The collection and numbering of samples conformed to the requirements of the Health Authority ethics committee. Each patient's sex, age, postal district of residence, general practitioner, and triage group were noted, in addition to whether the patients declared their HIV positivity while in A\&E. Data were collected on whether procedures which might involve exposure to blood were performed on each patient and also the subsequent destination of patients (that is, discharged or admitted to medical, surgical, or HIV medicine wards). ${ }^{3}$ In addition, these details were obtained for patients who did not agree to participate in the study ( $\mathrm{n}=8,0.25 \%)$. No patients were included in the study who were directly referred to the medical, surgical, or the HIV medicine team. The adequacy of urine and blood samples and the rigorous conditions for testing samples for anti HIV-1 and HIV-2 antibodies (that is, IgG quantitation, enzyme linked immunosorbent assays, and western blotting) were performed as before. ${ }^{2}$ The results of the study are shown in the table. The seroprevalence rate of $\mathrm{HIV}-1$ infection has risen to 1 in 30 for male and female patients

Hospital Medical

School, London W2

M C Poznansky

$\mathrm{J}$ Weber

Hepatitis and

Retrovirus Laboratory,

PHLS Virus Reference

Division, Central

Public Health

Laboratory, London

NW9

J V Parry

K Lewis

Correspondence to:

Dr Mark Poznansky, Jefferiss

Research Trust Laboratories,

St Mary's Hospital Medical

School, Praed Street,

London W2 INY.

Accepted for publication 24 April 1996

\begin{tabular}{|c|c|c|c|}
\hline & HIV negative (\%) & HIV positive (\%) & Pvalue* \\
\hline \multicolumn{4}{|c|}{ Number of patients providing urine or blood samples } \\
\hline $\mathrm{IgG}>0.1 \mathrm{mg} / \mathrm{ml}$ & $1066(98.2)$ & $19(1.8)$ & \\
\hline Number $(\%)(95 \% \mathrm{CI})$ of men & $624(56)(51.6$ to 60.4$)$ & 14 (74) (72.9 to 75.1$)$ & $<0.001$ \\
\hline Number $(\%)(95 \% \mathrm{CI})$ of women & 442 (44) (40.9 to 47.1$)$ & 5 (26) $(25.8$ to 26.2$)$ & $<0.01$ \\
\hline \multicolumn{4}{|l|}{ Number $(\%)(95 \% \mathrm{CI})$ of age } \\
\hline $16-25$ years & $224(21)(17.5$ to 24.5$)$ & $1(5)(4.7$ to 5.3$)$ & NS \\
\hline $25-49$ years & 352 (33) (28.8 to 37.2$)$ & $18(95)(94.0$ to 96.0$)$ & $<0.001$ \\
\hline $49-99$ years & $490(46)(41.6$ to 50.4$)$ & $0(0)$ & $<0.001$ \\
\hline Number $(\%)(95 \% \mathrm{CI})$ with GP & 757 (71) (66.8 to 75.2$)$ & $12(63)(62.1$ to 63.9$)$ & NS \\
\hline Number $(\%)(95 \% \mathrm{CI})$ foreign visitor & 213 (20) (16.7 to 23.3 ) & $4(21)(20.3$ to 21.7$)$ & NS \\
\hline Number $(\%)(95 \% \mathrm{CI})$ with open wound & $181(17)(13.7$ to 20.3$)$ & $5(26)$ & NS \\
\hline Number (\%) major illness triage category & $354(34)$ & $12(63)$ & $<0.001$ \\
\hline Number $(\%)$ declared HIV positive & $0(0)$ & $5(25)$ & $<0.001$ \\
\hline \multicolumn{4}{|l|}{ Number $(\%)$ admitted under } \\
\hline Medical team & $95(9)$ & $2(10)$ & NS \\
\hline Surgical team & $27(2.5)$ & $0(0)$ & NS \\
\hline HIV medicine team & $0(0)$ & $2(10)$ & NS \\
\hline
\end{tabular}

CI, confidence interval

${ }^{\star} \chi^{2}$ test, $\mathrm{df}=1$. 